Soedirman Accounting Review 1 (1) Desember 2016

\title{
PENGUJIAN AWAL PENGARUH FAKTOR INTERNAL \& EKSTERNAL PERUSAHAAN TERHADAP PREDIKSI KEBANGKRUTAN PERUSAHAAN
}

\author{
Abdul Azis ${ }^{1)}$, Adhelia Desi Prawestri ${ }^{1)}$, Adi Wiratno ${ }^{2)}$ \\ ${ }^{1)}$ Mahasiswa Magister Akuntansi Fakultas Ekonomi Universitas Jenderal Soedirman \\ Jl. HR. Boenyamin No. 708 Purwokerto 53122 Jawa Tengah Indonesia \\ ${ }^{2)}$ Dosen Magister Akuntansi Fakultas Ekonomi Universitas Jenderal Soedirman \\ Jl. HR. Boenyamin No. 708 Purwokerto 53122 Jawa Tengah Indonesia \\ *corresponding author: adheliaprawestri@gmail.com
}

\begin{abstract}
ABSTRAK
Tujuan dari penelitian ini adalah untuk mengetahui pengaruh faktor internal dengan proksi manajemen laba dan faktor eksternal dengan proksi penyisihan penurunan nilai piutang terhadap manajemen laba perusahaan. Penelitian ini merupakan penelitian kuantitatif dengan objek penelitian berupa perusahaan sektor pertanian di BEI selama tahun 2012 hingga tahun 2015. Pengambilan sampel menggunakan teknik purposive sampling atau pengambilan sampel bertujuan agar data yang didapatkan lebih bervariasi. Berdasarkan hasil penelitian, dapat disimpulkan bahwa faktor internal manajemen laba yang digambarkan dengan pendapatan komprehensif lain memiliki pengaruh positif terhadap prediksi kebangkrutan di sektor pertanian BEI dan faktor eksternal risiko eksternal yang digambarkan dengan penyisihan penurunan nilai piutang tidak memiliki pengaruh terhadap prediksi kebangkrutan di sektor pertanian BEI.
\end{abstract}

Kata kunci : Manajemen Laba, Pendapatan Komprehensif Lainnya, Penyisihan Penurunan Nilai Piutang, Prediksi Kebangkrutan

\section{ABSTRACT}

The purpose of this study is to determine the effect of internal factor with the earning management as a proxy, and eksternal factor with allowance for impairment of receivables as a proxy to the earning management. This study was a qualitative research with agricultural sector company as objects along 2012 to 2015. By using purposive sampling techiques intended that the data obtained more varied because it comes from varied sources. According to the results, it can be concluded that the internal factors of earning management with the other comprehensive income as a proxy had a positive influence on the prediction of bakruptcies in the agricultural sector and the external factors with external risk that described by premises allowance for impairment of receivables does not have an influence on the prediction of banrkruptcies in the agricultural sector in BEI.

Keywords : Earning Management, Other Comprehensive Income, Provision for Impairment of Receivables, Bankruptcy Prediction

\section{PENDAHULUAN}

Pesatnya pertumbuhan ekonomi global yang terjadi dewasa ini secara disadari maupun tidak telah mengakibatkan persaingan antar perusahaan yang semakin terbuka. Masing-masing perusahaan dituntut untuk selalu melakukan inovasi terhadap produk yang dihasilkan, melakukan peningkatan kinerja dan sumber daya manusia agar terus mampu menjadi pemain dalam dunia perdagangan yang semakin berkembang. Pihak manajemen harus mampu memenuhi tujuan utama didirikannya perusahaan yaitu untuk mensejahterakan pemilik dengan mengoptimalkan keuntungan dengan cara melakukan pengendalian perusahaan terhadap kinerja operasional terutama yang berkaitan dengan keuangan perusahaan.

Kemampuan perusahaan untuk dapat terus bersaing sangat ditentukan oleh kinerja perusahaan tersebut, meskipun ada beberapa faktor eksternal yang berasal dari pasar yang tidak 
mungkin dihindari oleh perusahaan. Kinerja perusahaan yang baik akan membawa perusahaan untuk tetap berjaya, sedangkan kinerja perusahaan yang buruk akan membuat perusahaan menjadi mengalami kesulitan keuangan yang berakir pada kebangkrutan perusahaan tersebut.

Perusahaan didirikan dengan asumsi bahwa perusahaan tersebut akan going concern atau terus tetap berdiri untuk selamanya, sehingga manajemen perusahaan akan mengupayakan segala cara untuk dapat mempertahankan kinerja perusahaan agar tetap baik dan tidak terjadi potensi kebangkrutan di masa yang akan datang. Perusahaan yang berada pada negara yang sedang mengalami kesulitan ekonomi akan lebih cepat mengalami kebangkrutan karena kesulitan ekonomi negara akan memicu kebangkrutan perusahaan (Darsono dan Ashari, 2005). Namun, kebangkrutan perusahaan tidak semata-mata disebabkan oleh faktor ekonomi saja, tetapi juga ada faktor lain yang sifatnya non ekonomi yang dapat menyebabkan suatu perusahaan mengalami kebangkrutan.

Darsono dan Ashari (2005) mendeskripsikan bahwa secara garis besar penyebab kebangkrutan bisa dibagi menjadi dua yaitu faktor internal dan faktor eksternal. Faktor internal adalah faktor yang berasal dari bagian internal manajemen perusahaan seperti manajemen yang tidak efisien, ketidakseimbangan modal yang dimiliki, serta adanya kecurangan yang dilakukan oleh manajemen perusahaan. Sedangkan faktor eksternal bisa berasal dari faktor luar yang berhubungan langsung dengan operasi perusahaan atau faktor perekonomian secara makro seperti perubahan selera konsumen, kesulitan bahan baku, debitor yang curang, hubungan yang tidak harmonis dengan kreditor, persaingan bisnis maupun kondisi perekonomian global yang harus selalu diantisipasi oleh perusahaan.

Kebangkrutan perusahaan merupakan salah satu fenomena yang sering terjadi didalam dunia usaha yang dapat dipengaruhi oleh kondisi internal maupun eksternal perusahaan. Untuk mengatasi dan meminimalisasi terjadinya kebangkrutan, perusahaan dapat mengawasi kondisi keuangan dengan menggunakan teknik-teknik analisis laporan keuangan. Analisis laporan keuangan merupakan alat yang penting untuk memperoleh informasi yang berkaitan dengan posisi keuangan perusahaan serta hasil yang telah dicapai sehubungan dengan pemilihan strategi perusahaan yang telah ditetapkan. Dengan melakukan analisis laporan keuangan perusahaan, maka dapat diketahui kondisi dan perkembangan financial perusahaan. Selain itu, juga dapat diketahui kelemahan serta hasil yang dianggap cukup baik dan potensi kebangkrutan perusahaan tersebut (Indah, 2014).

Menganalisis prediksi kebangkrutan suatu perusahaan sangat penting dilakukan oleh berbagai pihak seperti manajemen perusahaan maupun investor. Hal ini dikarenakan dampak dari kebangkrutan yang terjadi pada suatu perusahaan tidak hanya akan merugikan perusahaan saja tetapi juga pihak lain yang berhubungan dengan perusahaan tersebut. Oleh karena itu, analisis prediksi kebangkrutan dapat dilakukan untuk memperoleh warning terhadap adanya potensi kebangkrutan pada suatu perusahaan. Semakin dini peringatan tersebut diketahui, maka akan semakin baik bagi pihak-pihak yang berkepentingan dengan perusahaan tersebut. Manajemen perusahaan dapat segera 
Pengujian awal pengaruh faktor internal...

melakukan perbaikan terhadap perusahaan agar prediksi tersebut tidak terjadi. Selain itu, bagi pihak eksternal perusahaan, prediksi ini dapat digunakan sebagai landasan pengambilan keputusan finansial.

Kebangkrutan merupakan persoalan serius dan memakan biaya (Hanafi, 2011), maka jika ada early warning system yang dapat digunakan untuk mendeteksi potensi kebangkrutan perusahaan sejak jauh-jauh hari maka manajemen perusahaan akan sangat terbantu. Manajemen dapat melakukan kegiatan perbaikan yang diperlukan oleh perusahaan sedini mungkin untuk menghindari terjadinya potensi kebangkrutan. Prediksi kebangkrutan berfungsi untuk memberikan panduan bagi pihak yang berkepentingan tentang kinerja keuangan perusahaan apakah akan mengalami kesulitan atau tidak dimasa yang akan datang. Bagi pemilik perusahaan dapat digunakan untuk memutuskan apakah ia akan tetap mempertahankan kepemilikannya di perusahaan tersebut atau menjualnya dan kemudian menanamkan modalnya di tempat lain. Sedangkan bagi pihak yang berada di luar perusahaan khususnya para investor untuk menilai kondisi keuangan dan hasil operasi perusahaan saat ini dan dimasa lalu serta sebagai pedoman mengenai kinerja perusahaan dimana perusahaan tersebut apakah akan berpotensi untuk bangkrut atau tidak.

Pada sepanjang taun 2012 hingga tahun 2015, ada sebanyak 15 perusahaan yang telah didelisting oleh Bursa Efek Indonesia. Fatmawati (2012) mengatakan bahwa salah satu indikator bangkrutnya suatu perusahaan di pasar modal adalah dengan delistingnya perusahaan tersebut. Itu artinya selama kurun waktu 4 tahun terakhir sudah terdapat 15 perusahaan yang secara tidak langsung telah dinyatakan bangkrut.

Melihat kondisi perekonomian Indonesia yang kini tergabung sebagai anggota masyarakat ekonomi asia, maka beberapa sektor usaha perlu secara intensif terus dikembangkan sebagai sektor penghasil komoditas unggulan negeri ini. Salah satu sektor yang perlu diperhatikan adalah sektor pertanian. Selama kurun waktu 4 tahun terakhir sektor ini kini semakin mengalami penurunan kinerjanya. Sebagaimana dapat dilihat dari data statistik bursa efek indonesia beberapa perusahaan pada sektor ini mengalami kerugian operasional dimana laba sebelum pajak perusahaan-perusahaan tersebut kian tahun kian menurun. Penurunan kinerja operasional perusahaan-perusahaan sektor pertanian dikhawatirkan akan menjurus pada prediksi kebangkrutan perusahaan. Pada sektor ini terjadi sebuah fenomena menarik dimana beberapa perusahaan dalam beberapa tahun beruntun melakukan revaluasi aset sehingga diperoleh penghasilan komprehensif lain yang tinggi guna menutupi kerugian operasional sehingga angka laba yang disajikan bernilai positif.

Perusahaan sektor pertanian juga melakukan berbagai treatment dalam mengatasi risiko bisnis dengan menaksir penurunan nilai dalam laporan keuangan perusahaan diantaranya penurunan penilaian perusahaan dan penurunan nilai piutang. Pada konteks penurunan nilai persediaan biasanya perusahaan menjelaskan penurunan nilai dicadangkan karena adanya resiko kebakaran, supply chain error dan lain lain. Namun lain halnya pada konteks penurunan nilai piutang dimana penaksiran penurunan piutang tidak diberikan penjelasan secara memadai pada catatan atas laporan keuangan. 
Hal ini menyebabkan pembaca laporan keuangan perusahaan tidak mengerti secara jelas besaran cadangan penurunan nilai tersebut yang merupakan taksiran dari manajemen. Taksiran penurunan piutang pun memiliki range yang sangat tinggi antara perusahaan pertanian yang satu dengan yang lain. Ada perusahaan yang mencadangkan penurunan nilai piutang dalam kisaran jutaan, ada yang dalam kisaran ratusan juta, milyaran dan bahkan ratusan milyar. Hal ini menimbulkan pertanyaan besar mengenai kondisi perusahaan yang tidak transparan dan terdapat indikasi seperti apa dalam cadangan penurunan nilai putang.

Berdasarkan latar belakang masalah yang telah dikemukakan dan penelitian terdahulu yang belum membahas dari sisi yang berbeda maka penulis tertarik untuk melaksanakan penelitian dengan judul "Pengujian Awal Pengaruh Faktor Internal dan Eksternal Perusahaan terhadap Prediksi Kebangkrutan Perusahaan".

\section{TINJAUAN PUSTAKA DAN PERUMUSAN HIPOTESIS}

\section{Signaling Theory}

Signalling Theory atau teori sinyal menyatakan bahwa pihak eksekutif perusahaan memiliki informasi lebih baik mengenai perusahaannya akan terdorong untuk menyampaikan informasi tersebut kepada calon investor agar harga saham perusahaannya meningkat. Hal positif dalam signalling theory dimana perusahaan yang memberikan informasi yang bagus akan membedakan mereka dengan perusahaan yang tidak memiliki "berita bagus" dengan menginformasikan pada pasar tentang keadaan mereka, sinyal tentang bagusnya kinerja masa depan yang diberikan oleh perusahaan yang kinerja keuangan masa lalunya tidak bagus tidak akan dipercaya oleh pasar (Wolk dan Tearney 1997).

\section{Agency Theory}

Jensen dan Meckling (1976), Watts dan Zimmerman (1986) menyatakan bahwa laporan keuangan yang dibuat dengan angka-angka akuntansi diharapkan dapat meminimalkan konflik diantara pihak-pihak yang berkepentingan. Dengan laporan keuangan yang dilaporkan oleh agen sebagai pertanggungjawaban kinerjanya, principal dapat menilai, mengukur dan mengawasi sampai sejauh mana agen tersebut bekerja untuk meningkatkan kesejahteraannya serta sebagai dasar pemberian kompensasi kepada agen.

\section{Asimetri Informasi}

Asimetri informasi adalah suatu keadaan dimana manajer memiliki akses informasi atas prospek perusahaan yang tidak dimiliki oleh pihak luar perusahaan. Agency theory mengimplikasikan adanya asimetri informasi antara manajer (agent) dengan pemilik (principal). Kurangnya informasi pihak luar mengenai perusahaan menyebabkan mereka melindungi diri mereka dengan memberikan harga yang rendah untuk perusahaan. Perusahaan dapat meningkatkan nilai perusahaan, dengan mengurangi 
Pengujian awal pengaruh faktor internal...

informasi asimetri. Salah satu cara untuk mengurangi informasi asimetri adalah dengan memberikan sinyal kepada pihak luar tentang informasi keuangan yang dapat dipercaya yang akan mengurangi ketidakpastian mengenai prospek perusahaan yang akan datang (Wolk dalam Sadia, 2014). Dengan demikian, penerbitan laporan arus kas sebagai salah satu bagian dari laporan keuangan akan menyebabkan investor dapat menilai kondisi keuangan perusahaan dan mengurangi informasi asimetris.

\section{PENGEMBANGAN HIPOTESIS}

\section{Faktor Internal dengan Proksi Manajemen Laba Mempengaruhi Prediksi Kebangkrutan}

Manajemen laba yang dilakukan oleh para manajer pada pencatatan penyusunan laporan keuangan perusahaan menyebabkan informasi yang terkandung dalam laporan keuangan tidak akurat dan tidak menggambarkan nilai yang sesungguhnya. Manajemen laba yang dilakukan para manajer berdampak pada kualitas laba perusahaan, sehingga laba yang ditampilkan dalam laporan keuangan tidak menggambarkan secara akurat laba dari aktivititas bisnisnya. Proksi manajemen laba yang digunakan dalam penelitian ini adalah besarnya angka yang tercantum dalam akun Pendapatan Komprehensif Lainnya. Mayoritas perusahaan pertanian yang ada di Indonesia mengalami laba yang negatif selama beberapa tahun terakhir, tetapi laba tersebut kemudian menjadi positif ketika ditambahkan dengan akun pendapatan komprehensif lainnya. Hal ini berarti bahwa laba yang diperoleh perusahaan bukan laba real yang diperoleh berdasarkan kegiatan operasional perusahaan dan mengindikasikan adanya tindakan manajemen laba.

H1: Faktor internal dengan proksi manajemen laba yang digambarkan dengan pendapatan komprehensif lainnya berpengaruh positif terhadap prediksi kebangkrutan

\section{Faktor Eksternal dengan Proksi Penyisihan Penurunan Nilai Piutang Mempengaruhi Prediksi Kebangkrutan}

Penetapan prosentase piutang tak tertagih ditentukan berdasarkan pengalaman perusahaan atas piutang yang tidak dapat ditagih dari para debitur pada masa lalu. Besarnya persentase yang ditetapkan perusahaan dalam mengestimasi piutang tak tertagih ditentukan berdasarkan tanggal jatuh tempo piutang tersebut. Biasanya semakin lama jangka waktu jatuh tempo suatu piutang, maka semakin besarlah persentase yang ditetapkan untuk menaksir kerugian piutang tidak tertagih tersebut karena semakin besar pula risiko piutang tersebut tidak dapat ditagih kembali (Sihombing, 2013). Semakin tinggi perusahaan dalam menganggarkan penyisihan penurunan nilai piutangnya maka semakin baik karena perusahaan menganut prinsip konservatisme (kehati-hatian).

H2: $\quad$ Faktor eksternal dengan proksi penyisihan penurunan nilai piutang berpengaruh negatif terhadap prediksi kebangkrutan

\section{METODE PENELITIAN}


Penelitian ini dilaksanakan pada perusahaan pertanian yang terdaftar di Bursa Efek Indonesia (BEI). Pemilihan sektor ini didasarkan pada fakta di lapangan bahwa banyak perusahaan pertanian yang diindikasikan melakukan kegiatan manajemen laba melalui proksi pendapatan komprehensif lainnya yang tidak mencerminkan laba dari kegiatan operasi perusahaan sesungguhnya.

Populasi yang digunakan dalam penelitian ini adalah seluruh perusahaan pertanian yang terdaftar dalam Bursa Efek Indonesia (BEI). Untuk menentukan sampel dalam penelitian ini digunakan teknik purposive sampling penentuan sampel berdasarkan pertimbanganpertimbangan tertentu yang didasarkan pada tujuan penelitian. Sampel yang diambil dengan kriteria sebagai berikut: (1) Perusahaan pertanian go public yang periode laporan keuangan berakhir per 31 Desember. Kriteria ini dimaksudkan untuk menjamin bahwa dalam sampel tidak terdapat laporan keuangan parsial serta laporan keuangannya sudah diaudit, sehingga dapat lebih dipercaya. (2) Perusahaan pertanian yang menyampaikan laporan keuangan secara berturut-turut dari periode tahun 2012 hingga tahun 2015. (3) Data-data perusahaan tersebut lengkap.

\section{Manajemen Laba}

Scott (1997) mendefinisikan manajemen laba sebagai berikut "Given that managers can choose accounting policies from a set (for example, GAAP), it is natural to expect that they will choose policies so as to maximize their own utility and/or the market value of the firm". Dari definisi tersebut manajemen laba merupakan pemilihan kebijakan akuntansi oleh manajer dari standar akuntansi yang ada dan secara alamiah dapat memaksimumkan utilitas mereka dan atau nilai pasar perusahaan. Earnings management diukur dengan proksi jumlah pendapatan komprehensif lainnya pada suatu perusahaan. Semakin besar jumlah pendapatan komprehensif lainnya maka semakin tidak baik bagi perusahaan karena mencerminkan laba yang didapatkan bukan dari hasil kegiatan operasi perusahaan, melainkan dari pendapatan lain-lain.

\section{Penyisihan Penurunan Nilai Piutang}

Fokus pelaporan dalam melakukan penaksiran piutang dagang yang tidak tertagih dengan persentase penjualan kredit adalah laporan laba rugi. Prosentase saldo piutang yang 
Pengujian awal pengaruh faktor internal...

dilakukan dalam menaksir piutang tak tertagih akan menimbulkan adanya penyisihan penurunan nilai piutang sebagai pengurang dari nilai bruto piutang yang dilaporkan dalam neraca. Dengan adanya penyisihan penurunan nilai piutang tak tertagih, maka jumlah piutang yang diungkapkan dalam neraca adalah sebesar nilai netto dari piutang tersebut. Penyisihan penurunan nilai piutang digunakan sebagai proksi dari faktor eksternal penyebab kebangkrutan. Semakin tinggi jumlah yang dimasukkan dalam akun penyisihan penurunan nilai piutang maka semakin baik karena perusahaan akan semakin hati-hati dalam melakukan kegiatan operasinya yang menandakan sifat konservatisme yang dimiliki oleh perusahaan.

\section{Prediksi Kebangkrutan}

Model Altman Z-Score merupakan indikator untuk mengukur potensi kebangkrutan suatu perusahaan yang merupakan skor yang ditentukan dari perhitungan rasio keuangan yang menunjukkan tingkat kemungkinan kebangkrutan perusahaan (Ramadhani, 2009). Formulanya adalah sebagai berikut:

Keterangan:

$\mathrm{Z}=$ bankruptcy index

$\mathrm{X} 1$ = working capital / total assets

$\mathrm{X} 2=$ retained earnings $/$ total assets

$\mathrm{X} 3=$ earnings before interest and taxes / total assets

$\mathrm{X} 4$ = book value of equity / book value of debt

$\mathrm{X} 5$ = sales $/$ total assets

\section{Metode Analisis Data}

Metode analisis yang digunakan dalam penelitian ini adalah statistik deskriptif (Ghozali, 2009), uji asumsi klasik yang terdiri dari uji normalitas, uji multikolinearitas, uji heteroskedastisitas dan uji autokorelasi, serta pengujian hipotesis dengan model:

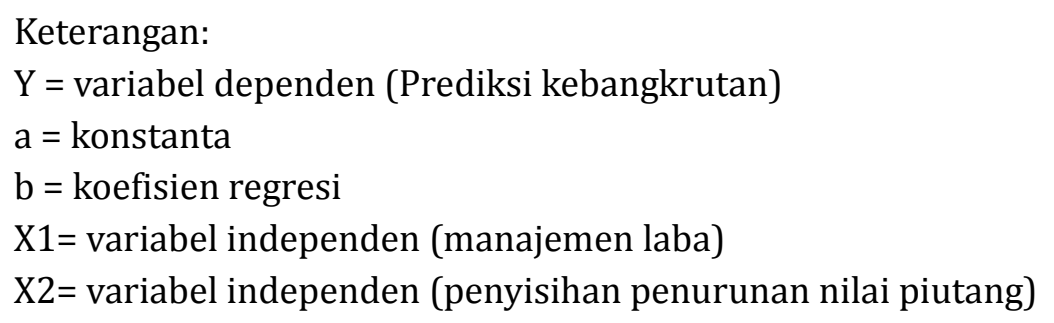

\section{PEMBAHASAN}




\section{Statistik Deskriptif}

Hasil dari analisis statistik dengan mengukur mean, median dan modus untuk masing masing variabel akan menunjukan kondisi sebenarnya dari sampel penelitian sehingga peneliti dapat menggambarkan bagaimana tingkat prediksi kebangkrutan pada perusahaan di Sektor Pertanian pada Bursa Efek Indonesia. Berdasarkan data yang diperoleh selama kurun waktu pengamatan sejak tahun 2012 hingga 2015 diperoleh informasi yang dijelaskan dalam tabel berikut :

Tabel 4.1 Statistik Deskriptif

\begin{tabular}{lrrr}
\hline Statistik Deskriptif & $Z$ Score & \multicolumn{1}{c}{$P K L$} & \multicolumn{1}{c}{$C P N$} \\
\hline Mean & 1,74 & $112.784,50$ & $101.282,59$ \\
Standard Error & 0,20 & $39.257,29$ & $45.385,43$ \\
Median & 1,54 & $14.100,00$ & 329,50 \\
Mode & - & 102,00 & $44.534,00$ \\
Standard Deviation & 1,12 & $222.072,79$ & $256.738,77$ \\
Kurtosis & $-0,33$ & 5,16 & 5,05 \\
Skewness & 0,76 & 2,40 & 2,53 \\
Range & 4,13 & $896.856,00$ & $952.359,37$ \\
Minimum & 0,29 & 23,00 & 17,63 \\
Maximum & 4,43 & $896.879,00$ & $952.377,00$ \\
\hline
\end{tabular}

Dari tabel diatas dapat kita ketahui bahwa kondisi sektor pertanian memang sedang lesu dan prediksi kebangkrutan pada perusahaan di sektor sangat tinggi. Hal ini ditunjukan dengan rata-rata nilai $Z$-score yang hanya mencapai 1,74 . Nilai tersebut mencerminkan bahwa rata-rata perusahaan sektor pertanian tidak memenuhi standar kesehatan perusahaan yakni nilai $Z$-score $>3$ namun tidak dikategorikan sebagai perusahan pailit karena nilai rata-rata berada pada kategori green area. Melihat fenomena tersebut maka dapat dikatakan bahwa sektor pertanian masih memerlukan tindakan pencegahan kebangkrutan dan mencari solusi untuk mengatasi kesulitan ekonomi yang sedang melanda. Dari 8 perusahaan sektor pertanian yang menjadi sampel penelitian, tidak semua perusahaan yang berpotensi mengalami kebangkrutan namun ada perusahaan yang secara keuangan dinilai masih sangat sehat yaitu dengan nilai $z$-score $>3$.

Beralih ke variabel independen Penghasilan Komperhensif Lain (PKL) diperoleh hasil bahwa Penghasilan Komperhensif Lain yang diakui oleh perusahan sektor pertanian rata-rata mencapai Rp 112,7 Milyar pertahun dengan pengakuan yang berasal dari revaluasi aset, pendapatan manfaat perpajakan, keuntungan translasi dan keuntungan kurs mata uang asing. Namun metode yang lebih dominan dalam mengakui Penghasilan Komprehensif Lain yang 
Pengujian awal pengaruh faktor internal...

dilakukan oleh perusahaan sektor pertanian adalah revaluasi aset tetap. Dengan menggunakan metode ini perusahaan sektor pertanian dapat mendapatkan penghasilan komperhensif lain paling tinggi mencapai Rp 896,8 Milyar. Namun tidak semua perusahaan sektor pertanian yang memaksimalkan Penghasilan Komprehensif Lain.

Deskripsi variabel independen Cadangan Penurunan Nilai (CPN) dari pengamatan tahun 2012 hingga 2015 pada perusahaan sektor pertanian diperoleh informasi bahwa manajemen perusahaan sektor pertanian rata-rata mencadangakan penurunan nilai piutang sebesar Rp 101 Milyar. Pengamatan melalui studi pustaka dan dokumentasi melalui Laporan Tahunan perusahaan sektor pertanian menunjukan bahwa pencadangan penurunan nilai piutang dilakukan oleh manajemen untuk merespon risiko pasar yang menyebabkan mitra usaha dan konsumen mengalami kendala yang berujung pada risiko gagal bayar sehingga untuk mengantisipasi hal tersebut manajemen melakukan penaksiran cadangan penurunan nilai piutang melalui analisis umur piutang. Beberapa perusahaan sektor pertanian mencadangkan piutang khususnya piutang untuk pihak ketiga yakni pada piutang dengan umur jatuh tempo yang kurang dari 60 hari dan manajemen perusahaan mengevaluasi dan menganggap bahwa mitra pihak ketiga tidak dapat menjamain pelunasan hutangnya.

\section{Uji Asumsi Klasik}

Uji asumsi klasik yang dilakukan pada model penelitian ini meliputi: Uji Normalitas, Heteroskedastisitas, Multikolinearitas dan Auto Korelasi. Berdasarkan hasil pengujian awal untuk variabel Z-Score, PKL dan CPN diperoleh hasil bahwa model penelitian tidak memenuhi uji asumsi klasik Normalitas, dan Heteroskedastisitas. Untuk mengatasi hal tersebut maka peneliti melakukan normalisasi data dengan metode tranformasi data Log natural sehingga variabel penelitian masih tetap dapat diuji secara kuantitatif. Setelah proses pengujian normaliasi data maka diperoleh data untuk masing masing Varibel Yaitu : Z-score, Ln_PKL dan Ln_CNP sehingga model penelitian dimodifikasi menjadi :

\section{Keterangan:}

$\mathrm{Y}=$ variabel dependen (Prediksi kebangkrutan)

$\mathrm{a}=$ konstanta

$\mathrm{b}=$ koefisien regresi

Ln_X1= variabel independen (manajemen laba) 
Ln_X2= variabel independen (penyisihan penurunan nilai piutang)

Setelah proses penormalan data kemudian dilakukan pengujian ulang untuk asumsi klasik dan hasilnya adalah seluruh data variabel penelitian memenuhi uji asumsi klasik normalitas, heteroskedastisitas, multikolineritas dan autokorelasi. Berdasarkan simultan dengan menggunakan uji $\mathrm{F}$ diperoleh bahwa variabel independen berpengaruh signifikan secara simultan terhadap variabel dependen (Fhitung 3,86 > Ftabel 3,31 dan signifikansi $>0,05$ ). Hal ini menunjukan bahwa model penelitian memenuhi uji kelayakan untuk dilanjutkan analisis regresi.

\section{Pengujian Hipotesis}

\section{Pengaruh Manajemen Laba (PKL) terhadap Prediksi Kebangkrutan}

Berdasarkan pengujian regresi berganda diperoleh hasil bahwa t hitung sebesar $-2,615<\mathrm{t}$ tabel $-2,359$ serta nilai signifikansi a $<0,05$. Hasil regresi tersebut menunjukan bahwa variabel independen manajemen laba dengan proksi Pendapatan Komprehensif Lain (PKL) memiliki pengaruh negatif signifikan terhadap kesehatan keuangan perusahaan. Maka dapat disimpulkan bahwa hipotesis penelitian yang menyatakan Faktor internal dengan proksi manajemen laba yang digambarkan dengan pendapatan komprehensif lainnya berpengaruh positif terhadap prediksi kebangkrutan diterima.

\section{Pengaruh Penyisihan Penurunan Nilai (CPN) terhadap Prediksi Kebangkrutan}

Berdasarkan pengujian regresi berganda diperoleh hasil bahwa t hitung sebesar $-0,364>\mathrm{t}$ tabel $-2,359$ serta nilai signifikansi a $>0,05$. Hasil regresi tersebut menunjukan bahwa variabel independen manajemen laba dengan proksi Penyisihan Penurunan Nilai Piutang tidak memiliki pengaruh signifikan terhadap kesehatan keuangan perusahaan. Maka dapat disimpulkan bahwa hipotesis penelitian yang menyatakan Faktor eksternal dengan proksi penyisihan penurunan nilai piutang berpengaruh negatif terhadap prediksi kebangkrutan ditolak.

\section{PEMBAHASAN}

Pengaruh Manajemen Laba (PKL) terhadap Prediksi Kebangkrutan 
Pengujian awal pengaruh faktor internal...

Dari hasil analisis diatas diperoleh hasil bahwa Pendapatan Komprehensif Lain berpengaruh negatif terhadap tingkat kesehatan perusahaan sektor pertanian mengindikasikan bahwa semakin tingginya Pendapatan Komprehensif Lain tidak selamanya menunjukan angka laba yang menjamin kesehatan keuangan sebuah perusahaan. Pengaruh negatif PKL terhadap kesehatan keuangan mencerminkan bahwa perusahaan dengan kesehatan yang tinggi akan melaksanakan tindakan manajemen laba berupa pengakuan Penghasilan Komprehensif Lain untuk menunjang angka laba operasional yang belum optimal.

Hasil penelitian ini membuktikan bahwa Semakin Tinggi Penghasilan Komprehensif Lain di Perusahaan Sektor Pertanian menunjukan tingginya tingkat prediksi kebangkrutan perusahaan. Hasil penelitian ini juga mendukung penelitian yang dilakukan oleh Hartas dan Sudarno (2012) bahwa usaha-usaha yang dilakukan manajemen dalam merekayasa laporan keuangan sering menggambarkan bahwa perusahaan dalam kondisi tidak baik. Seperti yang dijelaskan oleh Schipper (1989) yang mengartikan earnings management sebagai "disclosure management" dalam pengertian bahwa manajemen melakukan intervensi terhadap proses pelaporan keuangan kepada pihak eksternal dengan maksud untuk memperoleh keuntungan pribadi.

Adanya upaya untuk meningkatkan angka laba dengan metode pengakuan pendapatan komprehensif lain memiliki maksud agar informasi angka laba yang ditangkap dan direspon oleh pihak eksternal merupakan sebuah good news sehingga perusahaan akan memperoleh keuntungan baik dari sisi pasar modal maupun insentif keuangan manajemen. Yang perlu dikhawatirkan adalah bahwa angka laba dalam laporan keuangan dapat memberikan informasi yang menyesatkan sehingga pihak eksternal akan keliru dalam mengambil keputusan investasi bisnis. Kekhawatiran ini semakin besar ketika para investor hanya melihat angka laba tanpa memperhatikan komposisi laba perusahaan sehingga investor awam akan mengukur nilai perusahaan hanya dari laba bersih saja.

\section{Pengaruh Penyisihan Penurunan Nilai (CPN) terhadap Prediksi Kebangkrutan}

Dari hasil analisis diatas diperoleh hasil bahwa Cadangan Penurunan Nilai Piutang tidak berpengaruh terhadap tingkat kesehatan perusahaan sektor pertanian mengindikasikan bahwa semakin tingginya Cadangan Penurunan Nilai Piutang tidak akan mempengaruhi kesehatan keuangan sebuah perusahaan. Hal ini bisa dikarenakan bahwa perusahaan baik perusahaan dengan tingkat kesehatan yang tinggi maupun rendah mencadangkan penurunan nilai piutang berdasarkan risiko sistematis seperti inflasi, krisis dan perselisihan serta faktor 
politik sehingga seluruh elemen pasar merasakan dampak dari resiko sistematis tersebut tak terkecuali perusahaan sehat maupun perusahaan green area maupun perusahaan yang berpotensi pailit.

Koefisien negatif CPN terhadap kesehatan keuangan meskipun tidak signifikan namun memberikan gambaran bahwa perusahaan dengan kondisi kesehatan lebih baik akan mencadangkan penurunan piutang lebih kecil dari pada perusahaan dengan tingkat kesehatan lebih rendah. Hal ini mungkin dikarenakan bahwa perusahaan dengan kesehatan keuangan yang baik digambarkan dengan kondisi pengelolaan piutang yang baik pula sehingga perusahaan siap untuk mengatasi permasalahan piutang pihak ketiga. Hasil penelitian ini tidak mendukung penelitian yang dilakukan oleh Sihombing (2012) yang menyatakatn bahwa semakin tinggi kesehatan sebuah perusahaan maka akan semakin tinggi pula perusahaan menganggarkan penurunan nilai piutang dalam rangka menerapkan prinsip konservatisme.

\section{KESIMPULAN}

Hasil penelitian ini merupakan pengujian awal yang dilakukan dengan studi pelacakan dimana terdapat sebuah fenomena di Sektor Pertanian BEI yang ditemukan oleh peneliti. Hasil pengujian secara empiris dalam penelitian ini dapat memberikan wawasan dan pengayaan akademis di dunia pendidikan dan sekaligus sebagai bahan pertimbangan khususnya bagi investor dalam mengukur nilai perusahaan dan tingkat kesehatan perusahaan untuk tidak hanya terkonsentrasi pada angka laba bersih saja melainkan juga mempertimbangkan unsur manajemen laba yang mungkin dilakukan oleh perusahaan yang menyusun laporan keuangannya. Salah satu metode yang dapat dipertimbangkan untuk menilai manajemen laba yang telah dibahas dan terbukti dalam penelitian ini adalah angka Penghasilan Komprehensif Lain. Investor diharapkan untuk semakin jeli dalam mengukur nilai sebuah perusahaan ketika penilaian tersebut didasarkan pada laporan keuangan perusahaan.

Penelitian ini masih memiliki banyak keterbatasan diantaranya pengambilan sampel yang sempit hanya di dalam lingkup sektor pertanian sehingga penelitian selanjutnya dapat memperluas lingkup populasi dan sampel karena penerapan pada sektor yang berbeda akan memungkinkan mendapatkan hasil yang berbeda pula sehingga nantinya perbandingan antar sektor akan mungkin dilakukan. Penggunaan kriteria untuk mengukur manajemen laba masih dapat dikembangkan dan disesuaikan dengan kondisi industri sehingga diperoleh link and match antara dunia akademisi dan dunia bisnis agar dapat memperkaya ilmu pengetahuan 
Pengujian awal pengaruh faktor internal...

khususnya pada konsentrasi akuntansi. Penelitian ini juga terbatas pada fenomena-fenomena yang tertangkap oleh peneliti untuk tujuan pengujian awal sehingga penelitian selanjutnya dapat mengkombinasikan antara fenomena bisnis dan kekayaan literatur sehingga diperoleh penelitian yang lebih komprehensif. Faktor-faktor yang mempengaruhi kesehatan perusahaan atau prediksi kebangkrutan masih banyak yang belum dibahas dalam penelitian sehingga peluang untuk mengembangkan model penelitian masih sangat terbuka.

\section{DAFTAR PUSTAKA}

Akerlof, George A. 1970. The Market for "Lemons": Quality Uncertainty and the Market Mechanism. The Quarterly Journal of Economics, Vol. 84 No. 3.

Anthony, RN; Govindarajan, V. 1995. Management Control System. 8th Edition International Student Edition. USA: Richard D. Irwin Inc.

Astika, I.B.P. 2011. Konsep Dasar Akuntansi Keuangan, Denpasar: Fakultas Ekonomi Universitas Udayana.

Bahri, Syaiful. 2015. Analisis Prediksi Kebangkrutan pada Perusahaan yang Di-Delisting di Bursa Efek Indonesia. Jurnal Ilmu dan Riset Manajemen Vol. 4 No. 8.

Bringham, Eugene F. Dan Joel F Huston. 2001. Manajemen Keuangan Edisi Kedelapan. Jakarta: Erlangga. Darsono dan Ashari, 2005. Pedoman Praktis Memahami Laporan Keuangan. Yogyakarta: Andi.

Daswir, Fithri Aulia. 2010. Analisis Prediksi Kebangkrutan Perusahaan yang Listing di Daftar Efek Syariah Menurut Model Z-Altman. Working Paper.

Fatmawati, Mila.2012. Penggunaan The Zmijewski Modelm The Altman Model, dan The Springate Model Sebagai Prediktor Delisting. Jurnal Keuangan dan Perbankan Vol. 16 No. 1.

Ghozali, Imam. 2009. Aplikasi Analisis Multivariate dengan Program SPSS, Edisi keempat. Semarang: Badan Penerbit Univesitas Diponegoro.

Godfrey, et all. 2010. Accounting Theory 7th edition. Australia: John Wley and Sons Australia Ltd.

Hanafi, Mamduh M., Halim, Abdul. 2011. Analisa Laporan Keuangan. Yogyakarta: YKPN.

Hartas, MHR., Sudarno. 2012. Pengaruh Kualitas Audit, Kondisi Keungan, Manajemen Laba dan Mekanisme Corporate Governance terhadap Opini Audit Going Concer. Working Paper.

Healy, P. dan James M. Wahlen. 1998. A Review Of The Earnings ManagementLiterature And Its Implications For Standard Setting. Working Paper.

Indah, Tri Mustika. 2014. Analisis Model Z-Score Altman terhadap Prediksi Potensi Kebangkrutan pada Perusahaan Telekomunikasi yang Listing di BEI. Working Paper.

Jensen, C M., Meckling, W H. 1976. Theory of the Firm: Managerial Behavior, Agency Cost and Ownership Structure. Journal of Financial Economic, October 1976 Vol. 3 No. 4.

Linoputri, FP. 2010. Pengaruh Corporate Governance terhadap Penerimaan Opini Audit Goning Concern. Working Paper.

Marisanti, EK. 2012. Analisis Hubungan Profitabilitas terhadap Pengungkapan Intelectual Capital. JAAI Vol. 14 No. 1. 
Morris, R. D. 1987. Signaling, Agency Theory and Accounting Policy Choice. Accounting and Business Research, Vol. 18, No. 69.

Platt, Harlan D., dan Platt, Marjorie B. 2002. Predicting Corporate Financial Distress: Reflections on Choice-based Sample Bias. Journal of Economics and Finance. Illinois.

Richardson, Vernon J. 1998. Information Asymmetry and Earning Management: Some Evidence. Working Paper.

Ross, S. 1977. The Determination of Financial Structure: The Incentive Signalling Approach. Bell Journal of Economics pp. 23-40.

Sadia, Ni Putu Mia Diantari; Sukartha, I Made. 2014. Pengaruh Pergantian CEO pada Paktik Manajemen Laba Perusahaan Publik yang Terdaftar di BEI. E-Jurnal Akuntansi Univesitas Udayana Vol. 8 No. 1.

Schipper, Katherine. (1989). Comentary Katherine on Earnings Management. Accounting Horizon. Working Paper.

Scott, William R. 1997. Financial Accounting Theory (Ed.International). New Jersey: Prentice-Hall, Inc.

Sihombing, Halomoan. 2013. Akuntansi Piutang Usaha. Working Paper.

Spence, Michael. 1973. Job Market Signaling. The Quarterly Journal of Economics, Vol. 87 No. 3.

Tambunan, RW., Dwiatmanto, Endang MGW. 2015. Analisis Prediksi Kebangkrutan Perusahaan dengan Menggunakan Metode Altman (Z-Score). Jurnal Administrasi Bisnis Vol. 2 No. 1.

Watts, R, L and Zimmerman, J, L. 1986. Positive Accounting Theory: A Ten Year Perspective. The Accounting Review Vol. 60 No. 1.

Wolk, HI. And M.G. Tearney. 1997. Accounting theory: A Conceptual and Institutional Approach 4th Edition. International Thomson Publishing. 